Working

Paper

Department

of Economics

$\mathrm{Ca}^{\prime}$ Foscari University of

Venice

Luciano Pezzolo

The rise and decline of a great power:

Venice 1250-1650 


\title{
The rise and decline of a great power: Venice 1250-1650
}

\author{
Luciano Pezzolo \\ University of Venice \\ and School for Advanced Studies in Venice Foundation
}

\begin{abstract}
This essay outlines the rise and decline of the most powerful Italian republican state between the middle ages and the early modern period. It moreover seeks to analyze the political, financial, and military means that enabled a state based on a peripheral site and disposing of relatively limited population resources to achieve such a prominent position in Europe. It then examines the causes of its decline, in both relative and absolute terms. The history of Venice in fact offers an excellent case study with which to verify Schumpeter's thesis for a specific geographical area, that of the Italian peninsula, which has been surprisingly neglected by scholars interested in the origins of the fiscal state.
\end{abstract}

\section{Keywords}

War and economy, taxation, military power, state formation

\section{JEL Codes}

N43, E62, E63

Address for correspondence: inserire nome cognome

Department of Economics

Ca' Foscari University of Venice Cannaregio 873, Fondamenta S.Giobbe 30121 Venezia - Italy

Phone: (++39) 0412349150

Fax: (++39) 0412349176 e-mail: pezzolo@unive.it

This Working Paper is published under the auspices of the Department of Economics of the Ca' Foscari University of Venice. Opinions expressed herein are those of the authors and not those of the Department. The Working Paper series is designed to divulge preliminary or incomplete work, circulated to favour discussion and comments. Citation of this paper should consider its provisional character.

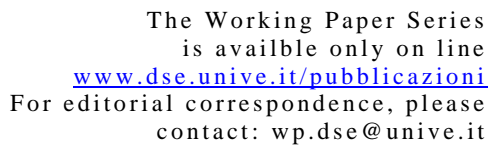

The Working Paper Series

is availble only on line www.dse.unive.it/pubblicazion For editorial correspondence, please contact:wp.dse@unive.it

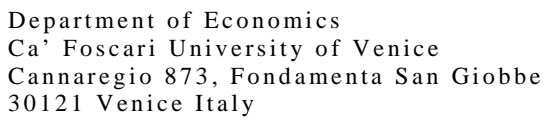


In the early 1570s Battista d'Agnolo del Moro painted a picture to be placed in the Camera dell'Armamento, the Republic of Venice's most important administrative office concerned with the navy. In the foreground we see three Provveditori all'armar (the patrician officials in charge of the Camera), in the midst of heavy sacks of coins. Under the vigilant gaze of St Mark they are handing money to a soldier dressed as an ancient Roman. In the background the doge and high dignitaries of the Republic take their leave of troops who are embarking on war galleys to the sound of drums and trumpets. The painting has a clear allegorical message. On the one hand, the figures of St Mark and the Roman soldier point out the sacred character of the war being conducted and its continuity with the military glories of ancient Rome. On the other hand, it lays stress on the close connection, of a much more prosaic kind, between money and war. The more mundane part of the scene represented by the picture - the war fleet preparing to sail, officials providing for its funding - was quite a usual sight for a Venetian spectator of the time, but the classical and religious references added by the painter imbued it with intense ideological meaning, while also underlining the massive extent of the government's mobilization of military and financial resources.

Venetian history is very closely bound to the sea: Venice rose from the sea, and its wealth and power came from the sea, which was indeed the primary cause of the prominent political and economic standing the Republic achieved. The symbiotic relationship between the lagoon town and the sea was considered so strong and binding that as soon as Venetians appeared to turn to the land, many voices were raised in complaint and deploration: they spoke of identity crisis, betrayal, and also of moral and economic decline. In reality the land was not the sea's antagonist in Venice's destiny, for the two elements integrated each other. The Republic's conquest of an extensive regional state in northeast Italy in the early 15th century was undertaken with the purpose of reinforcing its maritime interests. The control of the mainland proved necessary both to prevent the formation of a powerful, hostile regional state in the hinterland of the lagoon and to protect access to the inland trade routes - rivers, roads, mountain passes - that linked Venice to the markets of northern Italy and continental Europe. It was certainly the case that from the 16th century the Republic's ruling patriciate transferred its priority economic interests away from traditional maritime mercantile activity towards landowning. However, the maritime dimension of the state as a whole was not weakened: its overseas territories from Istria to the eastern Mediterranean continued to be defended with conspicuous military and financial resources. At the end of the seventeenth century, indeed, Venice even went to war to conquer the Peloponnese, thus seeking to acquire another kingdom in the Aegean as a way of compensating for Crete, lost to the Ottomans only a few years earlier after centuries of Venetian rule.

In this essay I will briefly outline the rise and decline of the most powerful Italian republican state between the middle ages and the early modern period. I will moreover seek to analyze the political, financial, and military means that enabled a state based on a peripheral site and disposing of relatively limited population resources to achieve such a prominent position in Europe. I will then examine the causes of its decline, in both relative and absolute terms. The history of Venice in fact offers an excellent case study with which to verify Schumpeter's thesis for a specific geographical area, that of the Italian peninsula, which has been surprisingly neglected by scholars interested in the origins of the fiscal state. 


\section{Expansion and contraction of maritime power}

What was perhaps the most important turning point in Venetian history occurred in 1202, when a specially commissioned Venetian fleet embarked the forces of the Fourth Crusade, which were supposed to go to the defence of the Holy Land. Their leaders had previously made a deal with the doge of Venice, committing themselves to pay the huge sum of 85,000 marks (about 20,000 kilos) of silver in exchange for the transport and supplies necessary for an army of 35,000 soldiers for a year. On arrival in Venice, though, the crusaders were unable to honour their commitment, and the Venetians succeeded in getting services from them in lieu of money. In 1204 the majority of the crusade army was diverted to Constaninople, and ended up creating the Latin Empire of the East. While the Latin emperors only lasted until 1261, Venice held onto the territorial gains it had made. It consolidated its position in Dalmatia and above all got Crete, Negroponte, Modon and Coron, as well as other strategic bases for the control of the sea routes between west and east. Venice was thus able to create a vast network of colonies that stetched from the Istrian peninsula towards the Black Sea.

These advantages gained by Venice in support of its Mediterranean trading drew a sharp reaction from Genoa, the other great Italian maritime power of the late middle ages. From the mid thirteenth century to the end of the fourteenth economic rivalry between the two was the cause of repeated warfare. The first war (1257-1270) was mainly fought in the eastern Mediterranean, and was won by Venice. In one of the decisive battles, off Acre in 1258, the Venetian fleet of 39 galleys, four big round ships and ten marette engaged a Genoese force of fifty galleys and four round ships. In another battle five years later, each side fought with about 30 galleys. The two rival republics used different strategies. Venice chose to defend its convoys with a strong escort of war galleys, counting on the superiority they had showed over the Genoese. After suffering severe defeats, the Genoese had instead decided to avoid largescale battles against the Venetian war galleys, and opted for a campaign of piracy against their enemy's merchant shipping ${ }^{1}$.

The second war between the two broke out in 1294 and began with a Venetian defeat. A year later Genoa rigged out a gigantic fleet of 165 galleys, carrying 35,000 men, though in the event the whole fleet was not wholly used. In 1298 the two republics' fleets - 90 Venetian ships against 80 Genoese - clashed off Curzola, in the northern Adriatic. Though the Genoese won, peace was signed a year later, because neither of the two rivals was able to prevail.

The fourteenth century saw two more wars between Venice and Genoa, in 1350-55 and 1378-81. These conflicts proved quite similar to their predecessors, as neither of the two adversaries succeeded in winning decisively. The fourth war against Genoa however brought severe consequences: it was, in Frederic Lane's words "the most severe test of the cohesion of Venetian society and of the strength of its republican institutions"2. Interests in the Black Sea were again the fuse that made the war explode. The early phases proved favourable to the Genoese and their allies, who in 1379 even entered the lagoon and threatened to occupy Venice itself, though in the end the Genoese were compelled to depart. It is interesting to note that this was the first war in which Venetian ships used artillery ${ }^{3}$. Equally significant, the number of warships manned was smaller than a century before,

\footnotetext{
${ }^{1}$ Lane (1973), 73-79.

${ }^{2}$ Lane (1973), 189.

${ }^{3}$ Lane (1973), 195.
} 
because of the decline of population after the Black Death and financial difficulties, and this trend was to continue for most of the fifteenth century, when military commitments in mainland Italy and the abatement of the rivalry with Genoa caused the reduction of the war fleet (Tab. 1).

\begin{tabular}{|c|c|c|c|c|c|}
\hline \multicolumn{3}{|c|}{$\begin{array}{r}\text { The Venetian navy } 1258-1603 \\
\text { galleys on service }\end{array}$} & \multicolumn{3}{|c|}{ in the Arsenal } \\
\hline & light & great & not spec. & $\begin{array}{l}\text { light } \\
\text { galleys }\end{array}$ & $\begin{array}{l}\text { great } \\
\text { galleys }\end{array}$ \\
\hline 1258 & 34 & & & & \\
\hline 1263 & 30 & & & & \\
\hline 1298 & & & 90 & & \\
\hline 1350 & & & 35 & & \\
\hline 1379 & 30 & & & & \\
\hline 1403 & 14 & & & & \\
\hline 1423 & & & 45 & & \\
\hline 1424 & 25 & & & & \\
\hline 1470 & 60 & & 18 & & \\
\hline 1499 & 48 & 17 & 25 & & \\
\hline 1504 & 83 & 32 & & & \\
\hline 1518 & 56 & 9 & & & \\
\hline 1525 & 25 & & & & \\
\hline 1537 & 82 & & & & \\
\hline 1538 & 65 & & & & \\
\hline 1539 & 72 & & & & \\
\hline 1540 & 36 & & & & \\
\hline 1541 & 25 & & & & \\
\hline 1542 & 25 & & & & \\
\hline 1543 & 36 & & & & \\
\hline 1544 & 18 & & & 131 & 12 \\
\hline 1545 & 22 & & & & \\
\hline 1546 & 18 & & & & \\
\hline 1547 & 20 & & & & \\
\hline 1548 & 19 & & & & \\
\hline 1549 & 21 & & & & \\
\hline 1550 & 28 & & & & \\
\hline 1551 & 48 & & & & \\
\hline 1552 & 47 & & & & \\
\hline 1553 & 32 & & & & \\
\hline 1554 & 31 & & & & \\
\hline 1555 & 25 & & & & \\
\hline 1558 & 59 & & 23 & & \\
\hline 1559 & & & & 120 & 6 \\
\hline 1560 & & & & 124 & 6 \\
\hline 1563 & & & & 114 & 9 \\
\hline 1568 & 30 & & & & \\
\hline 1569 & 45 & & & & \\
\hline 1570 & 140 & & & & \\
\hline 1571 & 130 & 9 & & & \\
\hline 1581 & 30 & & & 146 & 18 \\
\hline 1583 & & & & 117 & 18 \\
\hline $\begin{array}{l}1586 \\
1590\end{array}$ & 29 & & & $\begin{array}{l}95 \\
118\end{array}$ & $\begin{array}{l}18 \\
18\end{array}$ \\
\hline 1602 & & & & 135 & 8 \\
\hline 1603 & & & & 112 & 13 \\
\hline
\end{tabular}

Romano (1968), 69; Lane (1965), 230, 246; Pezzolo (1990), 134; Lane (1983), 198; Tenenti (1962), 121; Tenenti (1961), 158; Lane (1973), 73-79, 192, 199, 358, 360

Biblioteca del Museo Correr, Venice, Morosini-Grimani, 302, c. 113r; Biblioteca Nazionale, Florence, Capponi, 81, n. 19; Bibliothèque Nationale, Paris, Fonds it., 323, 16v, 283v; 
These military commitments in mainland Italy derived from the decisive phase of territorial annexations and state-building by the five main regional states in the peninsula, during the first half of the fifteenth century. In that brief period Venice succeeded in accumulating widespread dominions ranging from Friuli to Bergamo. Unlike the navy, Venice's land army was formed by mercenary troops along with a few Venetian soldiers, and we will shortly specify the difference between the Republic's military organization on land and at sea.

The fifteenth century saw the decline of Genoese commercial competition, but also the emergence of the Ottoman Empire, which was to pose the greatest military threat to Venice. In the first half of the century the navy was seldom involved in important campaigns but then a first, long war against the Turks in 1463-79 set a different tone for the second half of the century. Significantly it was Venice that started the war, a sign of government confidence in its military strength, particularly in the navy. Initial conquests were made in the Peloponnese, but subsequently the Ottomans employed their enormous military potential, blunting Venetian initiative. Turkish cavalry even penetrated the eastern provinces of the Venetian mainland, sacking and destroying minor settlements, while in the Aegean Sea Muhammad II's counteroffensive successfully conquered Negroponte, even though in the meantime the crusader kingdom of Cyprus passed under Venetian control.

1494 proved a year of destiny, with Charles VIII of France's campaign in Italy opening a new phase of Italian and European history. In the initial years of the Italian Wars (1494-1530) the republic of Venice achieved its greatest territorial expansion in the peninsula. Some ports in the southern Adriatic were conquered, so as to facilitate control of the Adriatic and Ionian, but then an unexpected Ottoman attack caused a first naval crisis. In 1499 a Turkish army conquered some Venetian bases in the Peloponnese, while other forces raided Venice's Italian dominion, arriving within a few kilometres of Venice itself; most important of all, the Ottomans got the better of the Venretians in the naval battle of Zonchio. This defeat had serious strategic and psychological consequences. The Venetian navy had previously considered itself much stronger than its Turkish counterpart, but the myth of its invincibility was now destroyed. In 1503 the Republic made peace giving up various colonies in Greece and Albania. The new century therefore opened with the Venetians forced to make a clear choice. They sought to maintain their maritime holdings by avoiding clashes with the Turks, and preferred to earmark most resources to the Italian front, where the Republic's destiny was at stake. The Italian Wars in fact absorbed enormous financial resources and forced the government to maintain an army that sometimes numbered as many as 30,000 men. Venice's role in the conflict was a mainly active one until the battle of Pavia (1525), but it subsequently applied to the Italian theatre too a strategy aimed at merely maintaining its existing holdings. A major defeat in 1509 had triggered the start of a gigantic and protracted program of fortification, with the purpose of defending Venetian territories from the western boundary of the Italian 
mainland state as far as Cyprus. These fortresses formed a true limes borrowing the term from Braudel - and represent Venice's strategic choice in visual terms as well: the defence of its territories and coastal bases.

The period between the early sixteenth century and 1670 saw the Ottoman Empire adopt a resolutely aggressive policy against Venice. The loss of Cyprus (1570), despite victory at Lepanto the following year, and the long war for Crete (1645-69) show Venice assuming a defensive stance, although possessing a good navy. It is superfluous to recall the key role played by the Venetian fleet at Lepanto, but worth underlining that it continued to represent a dangerous adversary in the seventeenth century too. This naval strength was nevertheless insufficient to prevent the loss of Crete, and therefore of Venice's most important Mediterranean base.

This very brief outline of Venetian naval activity is the premiss for a number of considerations. In the first place, the phases of Venetian economic growth and contraction were closely connected with the conjunctures of both the international economy and politics. The Venetians' ability to provide naval services allowed them to build a colonial empire dotted with bases and ports of considerable strategic importance. It is important to remember the frequency with which Venetian light or war galleys - the backbone of the navy - needed to restock with victuals and fresh water, given the limited storage on board. The possession of an almost continuous line of bases from the northern Adriatic to the Aegean Sea thus allowed the Republic to organize an effective escort for merchant shipping and general vigilance at sea. The Venetian military system was also characterized by considerable integration between the strictly naval component and land fortifications. It is no coincidence that Cristoforo $\mathrm{Da}$ Canal's mid-sixteenth century treatise on the Venetian navy in the midsixteenth century contains the picture of a galley inside a quadrilateral at whose four angles there are fortresses.

The conquest of Levantine territories represented an enormous source of wealth for Venice. The Venetian case corresponds rather closely to the model that Tilly calls "capitalised coercion". Military power aims at strengthening the state economically and helps create a market economy favourable to the needs of the ruling group. It has rightly been stated that the Venetian senate, the most important political organism in government, can be regarded as the Republic's board of directors. Until the early sixteenth century the majority of the senate's members were in fact patricians involved in maritime trade. One can thus argue that government decisions were strongly influenced by the requirements of international trade and merchants.

\section{Naval organization}

For most of the period considered here it is not easy to distinguish between ships used for trade and those with a strictly military function. While light galley squadrons regularly patrolled the northern Adriatic from the early fourteenth century, war fleets also included civil shipping, leased or 
requisitioned for war needs. For example the Venetian fleet at Zonchio in 1499 included fifty war or light galleys, but also some fifteen great or merchant galleys and twenty to thirty great carracks ${ }^{4}$. Venice was anyway distinguished by its capacity to fit out a large number of galleys from the late middle ages onwards. The one hundred galleys in wartime use by the end of the thirteenth century were a very considerable force, which no other state except Genoa could remotely rival. During the fifteenth century Venice was among the few powers that kept a standing fleet in peacetime too. The number of galleys at sea obviously fluctuated in relation to the political and military situation, and also to the weather. Their numbers decreased during wintertime, as many galleys went back either to Venice or to other Mediterranean bases. The light galley's structure allowed its safe use only during spring and summertime. There was an increase in the number of galleys in use during the sixteenth century In the 1520s the permanent fleet amounted to about 25 light galleys. During the Venetian-Turkish war of $1537-40$ the number increased to as many as 80 , and during the subsequent period of peace the fleet at sea numbered from 20 to over 40 ships. By the late sixteenth century the peacetime fleet had about 30 vessels: the Captain against Uskoks had two light galleys and three fuste under his command in the waters off Istria; four galleys commanded by the Governor of convicts patrolled the northern Adriatic, where there were another seven galleys under the Captain of the Gulf. The Proveditor of the Armata had a fleet of twelve galleys in the Ionian; four galleys of the Captain of the guard of Candia were based at Crete and another four galleys joined his squadron in summertime ${ }^{5}$.

In wartime the fleet could be increased to three or four times its peacetime strength. In the first year of the war of Cyprus (1570-73) Venice was able to equip 140 galleys; though some were destroyed or damaged by the weather, the following year at Lepanto there were 110 ships flying the standard of St Mark ${ }^{6}$. If the Venetian arsenal managed the remarkable feat of rapidly putting to sea more than a hundred fully equipped galleys, this was due to the ready availability of a reserve of galley hulls, whose quota was increased in 1524 from 50 to 100 units, of which 25 were always to be ready for immediate use ${ }^{7}$.

As to the seventeenth century, data concerning the navy are unfortunately relatively scanty. There were anyway two fleets in use: the light Armata, formed of light galleys, and the great Armata, that deployed large round ships driven only by sail and carrying a considerable number of cannon. Venice appears to have been unable to adapt quickly to the naval innovations that some northern European navies were experimenting. It was slow to adopt ships of the line, which came to dominate battles on the high seas, and continued to rely mainly on the light galley that had been proved so effective a weapon in earlier centuries of Mediterranean naval warfare. From the early seventeenth century the Venetian government bought Dutch

\footnotetext{
${ }^{4}$ Lane (1973), 360;

${ }^{5}$ Tenenti (1961), 158-59.

${ }^{6}$ Lane (1973), 369.

${ }^{7}$ Pezzolo (1990), 134-35; Tenenti (1962), 121.
} 
warships, thus admitting the state shipyard's technological limits, and only in the 1670s was a ship of the line actually constructed in Venice itself.

It would however be wrong to argue that Venice was never able to adopt technological innovations. It did experiment with new types of ships, for example the famous quinquereme built in the sixteenth century by Vettor Fausto, while measures were taken to improve light galleys' firepower. It is well-known that European and particularly Venetian artillery was of higher quality than the Turks'. The Arsenal stocked several cannon of different calibre suitable for mounting on the galleys; the navy as a whole also provides an interesting example of the standardisation of gun calibres. Sailors' individual weaponry comprised longbows and especially crossbows until the late fifteenth century. In 1518 the government decided to replace crossbowmen with arquebusiers; ten years later their number was increased from twenty to thirty-six per galley, and by mid-century it was about fifty, even though the number of arquebusiers was inferior to that usually found in other major fleets ${ }^{8}$.

All this does not however mean that Venetian naval strength was overall weaker than her adversaries'. The role played by the Venetian galleys at Lepanto is famous enough, and it is worth noting that during the long war for Crete in the mid-seventeenth century the fleet won important battles against the Turks. It is nonetheless true that the technological gap between Venice and the major north European navies widened between the sixteenth and the seventeenth centuries, as acknowledged by the government's purchase in the seventeenth century of Dutch and English ships, whose superiority it admitted. It was in the merchant navy that there was the greater gap in relation to northern competitors, for a variety of reasons. In Venice priority use of technological and material resources was reserved for the war fleet; the availability of such raw materials as oak and hemp had fallen from the sixteenth century onwards ${ }^{9}$. There was also a cultural element: the galley had proven to be an excellent naval tool, highly suitable for the characteristics of the Mediterranean sea; it provided those qualities of speed and manoeuvrability which naval war often fought close to coastlines required. And, as long as manpower was generously available, it represented the optimum point of balance between military and commercial needs. While the galley showed its limits in comparison with the ships of northern Europe, it was difficult for Venice to abandon a vessel that had proved decisive in naval war.

\footnotetext{
${ }^{8}$ Tenenti (1961), 39-40.

${ }^{9}$ Celetti (2002).
} 


\section{Logistics}

The Collegio da Mar, the most important magistracy in Venetian naval administration, was made up of patricians whose duty was managing the crucial sectors of navy organization: shipbuilding in the Arsenal, the provision of biscuit, the casting of artillery, the recruitment and payment of crews. Other patrician magistracies had charge of further specific issues, like for example the proveditors in charge of forests. The main management pattern of the navy was taking shape by mid-fifteenth century and achieved a stable, somewhat complex structure by mid-sixteenth century.

The organization and upkeep of a war fleet required a complex system for the control and management of materials, men and resources. Until the fifteenth century warfare had made considerable use of private shipping, but then Turkish pressure strengthened the importance of a strong, permanent core of state-owned warships. Consequently the emergence of a standing navy called for an intricate system for procuring and managing resources, various sectors of which will now be disvussed, together with an analysis of the complex relations between the navy and overall state activity.

\section{Behind the galleys: the Arsenal}

In the late middle ages Venice's state arsenal was justly famous all over Europe $^{10}$. It was first conceived simply as a shipyard, but in the fourteenth century it increasingly took on the functions of a veritable factory for producing shipping, especially big merchant galleys that could also be employed for war tasks, and light galleys. It must be stressed that the Venetian arsenal, like the Turkish one, included all the phases of production, from making sails to manufacturing gunpowder. It is wellknown that methods used in the construction of warships anticipated the factory system, in terms of the standardization of production and the degree of control over workforce. Equally important, from the mid-fifteenth century onwards it was Venetian government policy to keep a large reserve of light galleys. In 1525 the reserve was set at fifty galleys ready to be equipped; during the 1537-40 war it was increased to 100 light galleys and twelve great galleys, to which six galeasses were added in 1565 - a prescription which remained until $1633^{11}$. The Arsenal's performance proved excellent during the sixteenth century, when it achieved its peak production levels: thanks to the reserve, Venice was able to launch 100 galleys fully equipped in less than fifty days. After the 1570-73 war and then plague in 1576, a government order of 1577 re-established the reserve quota, though by 1582 it still had not been covered ${ }^{12}$. The next century, though conventionally labelled as the century of Venice's naval decline,

\footnotetext{
${ }^{10}$ Lane (1965), 125 ff.,; Davis (1991).

${ }^{11}$ Romano (1954), 49.

12 Venice, State Archives (thereafter ASV), Senato Mar, reg. 43, 117r (13-91577); reg. 44, 153r-v (30-2-1580); reg. 45, 103r (23-3-1582), 135v (14-81582).
} 
nonetheless witnessed considerable activity in the arsenal, which proved able to build about seven new light galleys a year ${ }^{13}$.

The arsenal's greatest problems concerned supplies of raw materials, in particular timber, gunpowder and hemp. It has been estimated that in the sixteenth century the annual need of timber for galley construction fluctuated between 50,000 and 60,000 cubic metres ${ }^{14}$. The appointment of proveditors with jurisdiction over state forests in Veneto and Istria from the mid-fifteenth century onwards reflected government concern about the availability of timber suitable for shipbuilding. Unauthorized tree-felling in these woods was strictly forbidden, and the control exercised seems to have got tighter in the sixteenth century, as severe difficulties emerged in finding timber. A significant sign of problems common to the whole Mediterranean basin is provided by the rise in the prices of oak for shipbuilding recorded at Genoa: they tripled between the 1460s and 1546-55, and by 1577-81 increased by twelve times since the $1460 \mathrm{~s}^{15}$.

Trees in the state forests were chosen for use by officers of the arsenal; felling and transport towards the lagoon were duties assigned to local rural communities, of course falling more heavily on mountain than on plain villages, though in case of need the latter were also required to contribute. The arsenal's timber needs were therefore responsible for both extensive government acction to defend forest resources of the republic, and corvées demanded of its rural subjects. Venetian policy in this area can probably be considered as one of the most precocious examples of the establishment of state control over the environment; though certainly prompted by military needs, this form of control obviously represents an important feature of relations between government and governed.

Being a fibre of strategic importance, hemp was also subject to state control $^{16}$. Hemp production was a crop specific to an area in the southeast of the mainland state, and was subjected to a monopoly system. The quality of Venetian hemp fibre however remained inferior to Bologna's, which continued to cover the majority of the arsenal's purchases. In the seventeenth century, with the navy incorporating new "northern" sailing ships, the arsenal's demand for hemp grew.

Natural resources were one of the Venetian authorities' major concerns, in relation to the quantities of raw materials available but also to their cost. As far as timber is concerned, it may be said that the Republic managed to establish a quite effective supply system; despite the increasing general difficulties in obtaining timber, the arsenal got conspicuous supplies for galley construction. The system's efficacy however implied negative consequences for many rural communities, heavily burdened by duties in the felling and transport of timber to the lagoon, with considerable costs deriving from this. As for hemp, the farmers growing it were subject to strict government control of both production levels and pricing. Overall, it

\footnotetext{
${ }^{13}$ Davis (1991), 81, 227.Consider that the arsenal of Marseille was unable to build annually more than seven galleys in the 1670s: Bamford (1973), 78.

${ }^{14}$ Agnoletti (1996), 1030.

${ }^{15}$ Calegari (1973), 94. See also the price of Venetian charcoal in Mckenney (1987), 102.

${ }^{16}$ Lane (1932); Pastori Bassetto (1993); Celetti (2001-02); Celetti (2003).
} 
appears likely that the Republic succeeded in trimming at least some raw material costs for its state shipbuilding, therefore enjoying an advantage in this respect over other Mediterranean powers.

\section{On board ship: weaponry and men}

A comparison between a fourteenth-century and a sixteenth-century galley would not show significant differences with regard to the main construction parameters, but would certainly reveal a marked change in the weaponry of both ship and crew. Starting from the second half of the fifteenth century, heavy ordnance spread throughout the Mediterranean, and individual firearms came into use in the following century. Until the late fifteenth century the weaponry of a Venetian light galley relied mainly on small weapons and crossbows used by sailors. Between the late fifteenth and the early sixteenth centuries some crucial innovations were made to galleys' weaponry: crossbows were replaced by arquebuses and some small cannon (basilisks, culverins...) were placed on board. In this sense Venice was quite quick in adapting her navy to technical change, and the Venetian galleys were better armed than the Turkish ships.

The galley's most important advantage consisted of its manoeuvrability, which was in large part due to the human engine made up of its of oarsmen (galeotti). They accounted for $75-80 \%$ of the men embarked, and were subject to frequent use during voyages. Unlike other powers, Venice refused to use convicts until quite late; the first convict galley with convicts went to sea as late as 1545 . There was a long tradition of free oarsmen who served in both the war fleet and merchant galleys. Until roughly the end of the fifteenth century the galleys mingled both commercial and military functions, so that there was a considerable overlap in the use of oarsmen between the war fleet and merchant galleys. In the event of war, merchant galley crews provided a notable contribution to manning the war fleet, and the flow was inverted as soon as peace returned. The traditional recruitment areas for oarsmen were the eastern coastline of the Adriatic, mainly Dalmatia, and also the Greek islands. But in case of need Venice's city population in general was also called on to serve. As early as the thirteenth century Venetians could be called up to serve as oarsmen along with volunteers. Conscription was practised on a rotation basis using groups of twelve men aged from sixteen to sixty or seventy years, listed for every city quarter. It is interesting to note that those drafted could choose the galley on which to serve, and therefore which captain to serve under; they could also hire substitutes to serve for them. This contributed to strengthen neighbourhood and clientage relations within the various city parishes, a network whose main protagonists were patricians ${ }^{17}$.

This system of neighbourhood-based conscription disappeared during the fifteenth century, with responsibility shifted towards other forms of organization of urban society: the Scuole (confraternities) grandi $e$ piccole and the guilds. Forms of social solidarity were in fact moving from a

\footnotetext{
${ }^{17}$ Lane (1973), 175; Zug Tucci (1997), 254-55; Aymard (1994), 438.
} 
territorial basis to an institutional one, with a crucial role in mediation played by religious confraternities and trade guilds ${ }^{18}$. From the 1480 s guilds and some religious institutions were called on to provide either oarsmen or money. During the Turkish war of 1537-40 the mechanism of recruitment was better organized. Venice and its immediate hinterland (the so-called Dogado) were to provide a total of about 20,000 conscripts enrolled in a galley rowers' reserve; those enrolled enjoyed some privileges (mainly access to some offices in urban administration) which were transferable to a son in case of death, and they received a wage during their period of actual service. Soon, however, those drafted paid for substitutes to serve in their stead, and the numbers of oarsmen assigned to the guilds and Scuole eventually represented a tax to be paid in cash. This brought about the emergence of a veritable market for rowers that drew men seeking money from afar.

The early sixteenth century also witnessed the establishment of a conscription system among the peasants of Venice's Italian mainland dominion $^{19}$. In 1522 the government decided to form a reserve of 6,000 men aged from 18 and 40 years to be trained as oarsmen. The mainland galeotti enjoyed significant fiscal and jurisdictional privileges and were treated like soldiers. They were allowed to bear the firearms given them by the authorities, they were exempt from personal taxes and they could not be condemned for debt during their period of service or for six months afterward. In 1537, on the occasion of the Venetian-Turkish war, the total number of rowers in the peasant reserve was increased to 12,000; in 1561 it numbered 10,000 men. Venetian patricians held rural oarsmen in little esteem; they usually were not effective and proved unsuited to life on board galley, and it is no coincidence that those enrolled from near lake Garda proved more suited to fleet service. During the second half of the sixteenth century the presence of mainland peasants on war galleys in fact declined, since government realized it was very difficult to get useful service from rural oarsmen ${ }^{20}$.

The other large area of recruitment for oarsmen was Venice's overseas dominion (the Dominio da mar), which included Dalmatia and the Greek islands. The sea colonies in fact represented the traditional recruiting area for the Serenissima's oarsmen, through both conscription and volunteer service $^{21}$. In 1350 at least ten galleys of a fleet of 35 were manned with oarsmen from Dalmatia and the Greek colonies ${ }^{22}$. Later on, the number of rowers coming from the colonies grew while that of the Venetians decreased. Tab. 2 shows that in the first half of the sixteenth century the peacetime standing fleet mostly relied on Dalmatian crews (the so-called schiavoni), who accounted for about half the men embarked, while Venetians and mainland peasants were added in the event of war. The Table furthermore shows that the role of convict galleys was still limited.

\footnotetext{
${ }^{18}$ Aymard (1994), 452.

${ }^{19}$ Hale (1983), 317-19.

${ }^{20}$ Tenenti (1962), 67.

${ }^{21}$ Jacoby (1981), for the Cretan case.

${ }^{22}$ Lane (1973), 175.
} 
The use of convicts as oarsmen was decided late in comparison with practice by other governments of the time ${ }^{23}$. Venetian patricians probably delayed this decision both for ethical reasons and because they had earlier not had serious difficulties in recruiting rowers in the labour market. When finally taken, the decision to equip galleys with convicts had a number of opponents in the senate, and the 1542 decree to institute the practice was actually put into effect only in 1545. In that year Cristoforo Da Canal, the commander who had supported the measure, was able to captain the first war galley manned with convicts ${ }^{24}$. The use and numbers of convict crews grew thereafter and by the end of the sixteenth century most of the fleet was made up of galleys rowed by convicts. It is nonetheless worth noting that Venice did not use slaves, who were widely employed in other Mediterranean fleets.

If the fleet's sailors and oarsmen came from a wide recruitment area extending from the Venetian mainland to the Aegean islands, its officers were almost always Venetian; only a certain number of galleys crewed by men from Dalmatia and Crete were commanded by local captains. Until the early sixteenth century a typical Venetian patrician was supposed to have spent part of his youth at sea. Sailing on the galleys with the title of noble crossbowmen, young members of the ruling élite began a cursus honorum that would take them from galley decks to merchant warehouses in the Levant, from service in embassies to the halls of power in the Ducal Palace. One of the most important characteristics of the Venetian ruling class's training was that patricians were subjected to a fast turn-over in the many offices of the Republic's political and administrative system. It was therefore unusual for any single patrician to remain a long time in an office in a specific sector of the government machine. As far as the navy is concerned, until the early sixteenth century the patricians who commanded galleys had already acquired considerable previous experience in naval matters. From the beginning of the sixteenth century, however, when merchants seldom sailed the sea routes in person, patricians breathed less and less sea air. It anyway needs stressing that naval commanders did not hold office for a long time, for they were required to switch to other duties. All this meant that Venice did not have a group of professional naval officers who made life aboard the galleys their definitive career choice. It would be wrong, however, to argue that seventeenth-century Venice lacked men suitable for naval warfare. The long war for Crete mid-century showed that the Venetian fleet was efficiently led and posed a permanent threat to the Turks. Although Venetians of that period were less familiar with the sea than their ancestors, the long naval tradition was maintained in official symbolism and exalted in family traditions. It was not difficult to come across mementoes of Lepanto or other naval battles in the halls of patrician palaces.

${ }^{23}$ Tenenti (1961), 147; Aymard (1974).

${ }^{24}$ Tenenti (1962), 78-115; Viaro (1981). 
Table 2

Composition of the Venetian fleet of galleys 1537-1554

\begin{tabular}{|c|c|c|c|c|c|c|c|c|c|c|c|c|c|c|c|c|c|c|c|c|c|}
\hline Crews & 1537 & 1538 & 1539 & 1540 & 1541 & 1542 & 1543 & 1544 & 1545 & 1546 & 1547 & 1548 & 1549 & 1550 & 1551 & 1552 & 1553 & 1554 & 1558 & tot & $\%$ \\
\hline of Schiavoni volunteers & 14 & 14 & 18 & 9 & 4 & 5 & 3 & 7 & 8 & 14 & 16 & 14 & 15 & 16 & 15 & 15 & 18 & 14 & 20 & 239 & 34 \\
\hline of Schiavoni conscripts & 8 & 8 & 5 & 5 & 1 & & & & & & & & & & & & & & & 27 & 4 \\
\hline of Venice & 11 & 22 & 23 & & & & & & & & & & & & & & & & & 56 & 8 \\
\hline of the mainland & 34 & 4 & 3 & 2 & 1 & 1 & 8 & & 2 & & & & & 6 & 12 & 8 & & & 18 & 99 & 14 \\
\hline of schiavoni and men of the mainland & 4 & & & 10 & & & & & & & & & & & & & & & & 14 & 2 \\
\hline of Dalmatian officers with conscripts & 8 & 14 & 12 & 10 & 9 & 9 & 9 & 6 & 6 & & & & & & 7 & 7 & 7 & & & 104 & 15 \\
\hline of the lake of Garda & 1 & 1 & & & & & & & & & & & & & & & & & & 2 & 0 \\
\hline of Burano & 1 & & & & & & & & & & & & & & & & & & & 1 & 0 \\
\hline of Chioggia & 1 & 2 & & & & & & & & & & & & & & & & & & 3 & 0 \\
\hline of the mainland and volunteers & & & 11 & & 10 & 10 & 10 & & & & & & & & & & & & & 41 & 6 \\
\hline conscripts and volunteers & & & & & & & 6 & 5 & 5 & 1 & & & & & & & & & & 17 & 2 \\
\hline of convincts & & & & & & & & & 1 & 3 & 4 & 5 & 6 & 6 & 7 & 7 & 7 & 7 & 8 & 61 & 9 \\
\hline of Candia & & & & & & & & & & & & & & & 6 & 9 & & 10 & 13 & 38 & 5 \\
\hline conscripts & & & & & & & & & & & & & & & 1 & 1 & & & & 2 & 0 \\
\hline
\end{tabular}

Source:

Biblioteca del Museo Correr, Venice, P.D. 396 cII, cc. 493r-v. 


\section{Funding}

Before examining the close relationship between finance and the navy, it is necessary to outline the Venetian fiscal system between the late middle ages and the early modern period. From the thirteenth to the seventeenth centuries the main revenues came from indirect taxes, levied on both trade and consumption. It is fairly probable that between mid-thirteenth and midfourteenth centuries peacetime income was enough to cover all the state's ordinary needs. Government was nevertheless compelled to seek new ways of financing expenditure by the growth of its military commitments and the consequences of expanding its dominions. By mid-fourteenth century the Republic's budget amounted to about 250,000 ducats (over 10,000 kilos of silver); before the Black Death the population of Venice itself was around 100,000. At the same time the French monarchy's budget can be estimated at about a million livres (44,000 kilos of silver), in relation to subjects totalling nearly a million. It therefore seems likely that Venice, even if we take account of the population of its dominions too, enjoyed a more favourable ratio between population and central government revenues than France ${ }^{25}$.

The good health of state finances depended on sound economic and military foundations. Venice managed to play a crucial part in international trade thanks to both the capability of its merchants and the efficient action of its mariners and soldiers. Emblematic of this successful combination of elements is Venice's handling of salt production and trading in the Adriatic $^{26}$. From the thirteenth century onwards Venice imposed its monopoly over salt trade in the Adriatic, subjecting the coastal towns producing salt to close control. Salt was imported by Venice and redistributed via excisemen - with high returns for state finance - to both Venetian subjects and neighbouring states. This hegemony exerted over the salt trade was the result of an aggressive policy pursued by means of military force in order to create unbalanced relations between salt producers and buyers, reserving a considerable profit for Venetian mediation.

A further example that stresses the use of violence to achieve economic ends is offered by Venice's assertion of sovereignty over the northern Adriatic ${ }^{27}$. As early as the mid-thirteenth century a squadron of galleys regularly patrolled the northern end of the Adriatic - which Venetians called the "Gulf" - in the name of a sort of right to control shipping ${ }^{28}$. Though there was no backing for it in universally recognized rights, Venice had imposed its jurisdiction over those waters and demanded a sort of tribute from coastal towns within the area. All ships entering the area were subject to checking by the Republic's galleys. A Venetian sea

\footnotetext{
${ }^{25}$ It is worth stressing that population data are little reliable. The transformation of French nominal figures is made complicated since in the first half of the fourteenth century the silver content of the livre largely fluctuated. For French data, Rolnick, Velde, Weber, “The debasement puzzle”, p. 797.

${ }^{26}$ Hocquet (1978-79).

${ }^{27}$ Bin (1992).

${ }^{28}$ By 1300 a permanent squad was maintained to patrol the Adriatic sea until the Apulian coast: Doumerc (1997).
} 
space had been created, with no formal legitimacy in international law but sanctioned by the exercise of military power.

Despite the clarity of these instances, it is however difficult to determine clearly the overall link between Venice's economic expansion and its military system. Despite the existence of a stable nucleus of war galleys, war fleets were mostly composed of merchant ships that were used for war in case of need. This meant that the permanent bureaucratic structures for naval organization were rather lightweight, and that most of the machinery set in motion in wartime was quickly dismantled with peace. Venice was nonetheless able to deploy a hundred galleys even after making peace with Genoa in 1299, in order to keep the Levantine commercial routes safe $^{29}$. As late as the fourteenth century protection costs were mostly borne by foreign traders and consumers. Venice's import-export of costly eastern goods like spices provided high returns that in the final analysis were paid for by European buyers of those goods. Furthermore war expenses, though high, showed no likelihood of undermining the structure of state finance: government managed to recover in a relatively short time from any financial crisis associated with war.

A crucial feature of the elasticity of state finance's mechanisms was the system of forced loans, which were imposed on Venetians in case of need. Urban élites were strongly opposed to ordinary direct taxation; one of the prerogatives that marked the differences between towndwellerss and peasants was that the former did not usually pay non-returnable direct taxes. In Venice, as well as in Florence or Genoa, the richest citizens were initially asked to lend money voluntarily to government in case of need; government committed itself to pay it back in a short time, and in the meanwhile paid interest on the loan. The system was however unable to cope with growing state expenditure and so from the end of the twelfth century it became the practice to impose interest-bearing forced loans. All citizens had to lend according to their wealth, which was assessed in public registers. Loans at first were usually reimbursed, but increasing difficulty in returning the principal led to the development of funded debts. In 1262 the Venetian government acknowledged its momentary incapacity to repay creditors, and therefore committed certain tax revenues to the regular payment of five percent interest p. a., and all loans were eventually transformed into longterm loans. War had thus prompted a crucial financial innovation: difficulties in covering war spending needs urged the adoption of a solution that allowed government to get huge amounts of money at a moderate cost, while at the same time not burdening citizens too much. Beside its financial effects, the funded debt had political implications too: Venetians had become the state's creditors, and their wealth directly concerned in the formulation and outcome of government's choices.

The foundations of Venetian power in the eastern Mediterranean were economic, financial and also ideological.. The war fleet was commanded by patrician-merchants, and crewed by paid sailors and soldiers from Venice and abroad; the money for war expenses and interest payment

${ }^{29}$ Doumerc (1997), 238. 
on the funded debt mostly came from customs duties. The forced loan mechanism converted Venetians' financial resources into an effective military force that, in its turn, helped to broaden and strengthen the material base from which to draw further financial resources. War was also felt to be a matter concerning the whole city, for it was considered as the most powerful means of preserving Venice's economic and political power. In the fifteenth century, however, this trade-off between private resources and public spending ceased to work beneficially when Venice expanded its dominions in the Italian peninsula and the Ottoman empire emerged as an expanding power in the Mediterranean.

The war against Genoa in 378-81 caused a severe financial crisis. Government forced loan demands grew but interest payments on old loans were cut simultaneously; the interest rate on credits was reduced to four percent, and the market price of state bonds dropped to $18 \%$ of par. Subjected to such heavy pressure, the forced loans system showed its limits of tolerance. Especially from the mid fifteenth century onwards government sought new ways of raising revenue: it resorted to direct taxation, which became semi-ordinary practice by mid-fifteenth century, and then ordinary during the sixteenth. From the early sixteenth century forced loans were seldom used and the government entered the open credit market. New series of loans were launched to raise money among investors. Underwriting was a free choice, the interest rate was higher than that of the old funded debt's Monti, and bonds were tradable and tax-free. The deficit finance mechanism was thus improved through financial innovations, which constituted a crucial step toward creating a more efficient state debt. These innovations were prompted by the increasing needs of military spending both at sea and on land.

The fifteenth century began with Venetian territorial expansion in the mainland, and included a long war against the Turks in 1463-79. It ended with the need for a titanic war effort. In 1499 the Venetian land army conquered Cremona, not far from Milan, and at the same time the Republic had to face both the Turkish fleet in the Aegean area and Turkish cavalry raids in the eastern mainland. Venice deployed about 20,000 soldiers in the Italian peninsula and 20,000 to 25,000 men in the fleet ${ }^{30}$. The size of the military machine was impressive: the land army was not smaller, in quantitative terms, than the French and Spanish ones, and the fleet was probably the most powerful among those of the Christian states. Furthermore, considering the ratio population/soldiers (Tab. 3), Venice shows one of the lowest figures in Europe, while that ratio actually halves if we also include the navy.

\footnotetext{
${ }^{30}$ On the fleet, Lane (1973); on the land army, Mallett and Hale (1984)
} 
Table 3

Rate population/soldiers in some countries

$\begin{array}{lrrrr} & 1500 & 1550 & 1600 & 1650 \\ \text { Spain } & 340 & 164 & 94 & 84 \\ \text { England } & 77 & 155 & 200 & 79 \\ \text { France } & 586 & 317 & 333 & 205 \\ \text { Low Countries } & & & 34 & 63 \\ \text { Piedmont } & & & & 57 \\ \text { Venice } & 64 & 254 & 120 & 125 \\ \text { Florence } & & 20 & 237 & 33 \\ \text { Rome } & 71 & & 667 & 127\end{array}$

Source:

Pezzolo (forthcoming).

If we consider the Venetian-Turkish war of 1570-73, the picture does not change. The military forces deployed were the outcome of a well-tested administrative and financial machine. In 1571, according to Venetian records, the infantry distributed throughout the Levant fortresses and embarked in the Armata were over 30,000; the fleet consisted of 130 light galleys and 9 galleasses. An estimate of the men serving under the symbol of St. Mark's winged lion gives a total of at least 55,000; consequently the ratio between population and men enrolled was 36 to $1^{31}$. In the years following Lepanto the Venetian forces were reduced, with the army amounting to about 10,000 soldiers in the fortifications, and the navy to some 6,000 sailors and oarsmen. In 1645, the first year of the war for Crete, the government issued orders to hire 25,000 soldiers, and in 1646 added another $7,000^{32}$.

These figures suggest that we should conduct a careful examinination of some features of Venetian state organization. Figure 1 shows the considerable percentage of revenue devoted to funding the military machine and servicing the public debt. The picture that emerges is not very different from other examples already studied ${ }^{33}$. Considering that state indebtedness was due to war needs, we can argue that military structures and the consequences of war constituted the majority of state expenditure. It is interesting to note that the growth of military expenditure was also due to the high inflation of the sixteenth century: between the midsixteenth century and the early seventeenth century the cost of a light galley doubled, for example. This growth rate was however lower than the price increase in foodstuffs over the same period.

\footnotetext{
${ }^{31}$ Estimated figures for the military strength from ASV, Secreta, Materie miste notabili, 123 bis.

${ }^{32}$ ASV, Senato Mar, regg. 103 and 104.

${ }^{33}$ An overview in Koerner (1995).
} 
Military machine and debt service (\% of state expenditure)

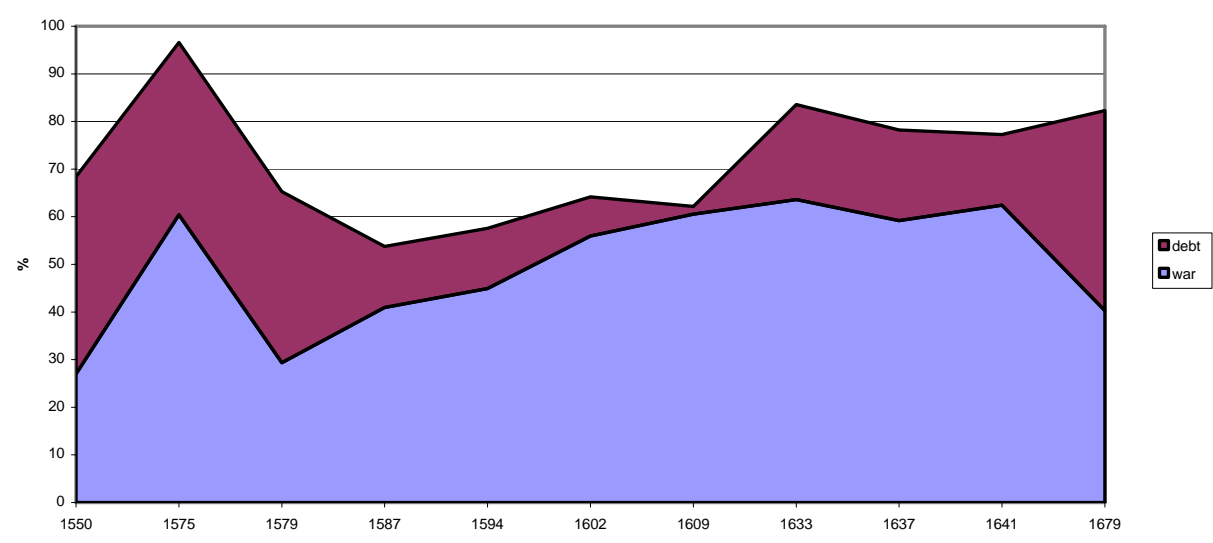

As for the navy, data are available starting from the sixteenth century. Tab. 4 shows that naval expenditure (fleet and arsenal) accounted for twenty to thirty percent of the total. Between the mid-sixteenth and the 1640 s Venice spent more than England in percentage terms ${ }^{34}$. From the 1550s to the 1630s funds earmarked to the navy roughly doubled, keeping up with the rise in prices, while state expenditure grew by nearly two times. Unlike what happened in England, however, Venetian government seems not to have invested in technological innovation. The Republic's navy showed relatively high standards, but it was certainly inferior to the navies of the powers that rose to prominence in the seventeenth century, namely England and the United Provinces.

${ }^{34}$ Figures in Wheeler (1999), 24, 27, 32. 
Expenditure of the Republic of Venice, 1550-1679

\begin{tabular}{|c|c|c|c|c|c|c|c|c|c|c|c|c|c|c|c|c|c|c|c|c|c|c|c|c|c|c|}
\hline & 1550 & $\%$ & 1555 & $\%$ & 1575 & $\%$ & 1579 & $\%$ & 1587 & $\%$ & 1594 & $\%$ & 1602 & $\%$ & 1609 & $\%$ & 1633 & $\%$ & 1637 & $\%$ & 1638 & $\%$ & 1641 & $\%$ & 1679 & $\%$ \\
\hline Arsenal & 100000 & 5,8 & 94000 & 5,5 & 237496 & 11,9 & 166000 & 10,7 & 161125 & 8,4 & 201451 & 9,5 & 201836 & 8,4 & 213033 & 8,2 & 159219 & 5,5 & 182751 & 6,3 & 181971 & 6,8 & 197835 & 7,2 & 235082 & 5,9 \\
\hline Fleet & 200000 & 11,5 & 250000 & 14,6 & 299987 & 15,1 & 230000 & 14,8 & 236395 & 12,3 & 326918 & 15,4 & 420767 & 17,5 & 535043 & 20,6 & 486698 & 16,8 & 499041 & 17,1 & 440965 & 16,5 & 474936 & 17,4 & 557434 & 14,1 \\
\hline Army & 212169 & 12,2 & 234500 & 13,7 & 614359 & 30,8 & 181020 & 11,6 & 323929 & 17,0 & 360474 & 27,0 & 608132 & 25,3 & 689437 & 26,5 & 984886 & 34,0 & 961648 & 33,0 & 832386 & 31,1 & 1016490 & 37,2 & 783914 & 19,8 \\
\hline Fortifications and artillerry & 26000 & 1,5 & 80000 & 4,7 & 26464 & 1,3 & 30788 & 2,0 & 52326 & 2,7 & 52150 & 2,5 & 154978 & 6,5 & 135101 & 5,2 & 55000 & 1,9 & 55000 & 1,9 & 55000 & 2,1 & 40000 & 1,5 & 19809 & 0,5 \\
\hline Public debt & 575301 & 33,2 & & & 705447 & 35,4 & 743213 & 47,7 & 242127 & 12,6 & 264889 & 12,5 & 203501 & 8,5 & 41619 & 1,6 & 527987 & 18,2 & 546491 & 18,7 & 483231 & 18,1 & 410381 & 15,0 & 1663000 & 42,0 \\
\hline Other & & & & & 107648 & 5,4 & 206107 & 13,2 & 898647 & 46,9 & 911629 & 43,1 & 812525 & 33,8 & 987545 & 38,0 & 682303 & 23,6 & 673268 & 23 & 682303 & 25 & 590909 & 22 & 702266 & 18 \\
\hline Total & 1734789 & 100 & 1717409 & 100 & 1991401 & 100 & 1557128 & 100 & 1914549 & 100 & 2117511 & 100 & 2401739 & 100 & 2601778 & 100 & 2896093 & 100 & 2918199 & 100 & 2675856 & 100 & 2730551 & 100 & 3961505 & 100 \\
\hline
\end{tabular}

Source:

Pezzolo (2003). 


\section{A fiscal-military state?}

In his book on eighteenth-century England John Brewer has pointed out the emergence of a fiscal-military state 'whose main features were: high taxes, a growing and well-organized civil administration, a standing army and the determination to act as a major European power ${ }^{35}$. Brewer's model, which to some extent echoes the content of pages written by Hintze, offers a useful parameter to check for characteristics of the fiscal-military state in the history of the Venetian republic.

First of all one has to ask whether Venetian policy, during the great phase of political and economic expansion from the thirteenth to the fifteenth centuries, was supported by significant elements of the model just described. At first sight Venetian government did not burden citizens with heavy tax demands, circumstances permitting; the bureaucratic structure was rather lightweight; neither a standing army nor a sizeable permanent navy existed; the only element in common with the model was the clear determination to achieve a prominent position in the Mediterranean theatre. But this poses a question: however did it prove possible for a city or citystate to maintain so much prominence for so long in the midst of international competition?

At first Venice filled a void caused by the decline of the Byzantine Empire. The lagoon city had grown in the shadow of Byzantium and managed to acquire elements of control within the Adriatic by replacing imperial power. That allowed Venice to play an increasingly important role in the Adriatic and then in more distant seas and, as we well know, to develop the functions of intermediary in longdistance commerce between west and east. If the Eastern Roman Empire was unable to block Venice's expansion, Genoa instead emerged as its most dangerous competitor. The other great maritime republic was the only rival able to trouble Venice, in terms of its economic and military strength. The four wars the two cities fought between the mid-thirteenth century and the late fourteenth century can be regarded as a long competition for the hegemony over a crucial area of the international economic system. The three wars fought by England and the United Provinces in the second half of the seventeenth century show several analogies with the Venetian-Genoese struggle. The two Italian cities were in the throes of powerful economic growth and were sited at what Wallerstein would term the core of the world-economy. Likewise, the later struggle between the English and Dutch was a contest for primacy in a wider world-economy. Wars prompted England to improve both her military machine and state finance, and laid the foundations of her subsequent primacy on the seas of the whole globe ${ }^{36}$.

It does not seem, on the other hand, that its wars against Genoa had pushed Venice to make remarkable improvements of her fiscal and military

\footnotetext{
${ }^{35}$ Brewer (1989).

${ }^{36}$ Wheeler (1992).
} 
system. As far as we know, the growth both of the demand for forced loans and of custom duties were the main means used to cope with greater military spending needs. At the end of the fourteenth century government attempted to impose a form of direct tax, but it was not intended as an ordinary tax. Venice's great advantage was in its capacity to transform commercial capital quickly into financial resources that in turn allowed it to maintain a powerful fleet. In military terms, Venice could dispose of effective naval resources. Its capacity both to put together a mighty fleet and to call on the services of skilled sailors was generally recognized, and it commanded enemies' respect. This naval strength did not depend on a robust, permanent bureaucratic structure, since the war fleet was mostly formed of ships temporarily deviated from mercantile activity; the specialization between war and merchant shipping had not yet emerged clearly and definitively. Nevertheless the Venetian fleet apperared solider than its Genoese counterpart: the whole Venetian population concentrated its efforts on the fleet, which was considered as the most powerful expression of the city's common will and sense of unity. The Genoese fleet, on the contrary, was made up of ships belonging to the various noble clans and they were primarily regarded as the expression of those leading families' power. It is likely that internal divisions in Genoa and deep tensions within its ruling group contributed to its naval defeats by Venice ${ }^{37}$. One can indeed argue that, paradoxically, Venice's naval success came about in the absence of a huge standing fleet, a high burden of taxation and extensive bureaucratic structures. Its true strength lay in its capacity to mobilize financial and human resources more effectively than its competitors. The labor-intensive character of medieval sea warfare did not press towards the creation of a complex administrative system, or therefore favour the emergence of state institutions specialized in war. Despite this Venice established an effective system for the control and supply of the resources needed for shipbuilding as well as a permanent recruitment system of sailors and oarsmen that involved both the capital and the dominions. Venice enjoyed comparative advantages that allowed it to achieve a role of crucial importance in the Mediterranean; starting in the fifteenth century, however, these advantages were to vanish, albeit only slowly.

Despite its victories, Venice was in fact unable to take full advantage of its position. From the mid-fifteenth century the Ottoman Empire put new pressure on Venetian overseas territories. Making a further comparison with England, we can state that, having once got rid of the Dutch, the English did not face other rivals as dangerous as them, and thus enjoyed enormous opportunities. Venice, on the other hand, once it had defeated Genoa, had then to cope with the much more militarily dangerous Ottoman Empire.

The true turning point of Venetian fiscal and military history occurred between the fifteenth and sixteenth centuries. Strongly militarily committed on both land and sea, the Republic made major reforms in its fiscal and military istitutions. During the fifteenth century a standing army

\footnotetext{
${ }^{37}$ A brief but interesting comparison between the Venetian and the Genoese fleets is made by Lane (1982), 78-79. A good account on medieval Genoa is Epstein (1996). See also Greif (1998).
} 
was established, with a wartime strength of many as 20,000 soldiers, and a permanent administrative structure was created to deal with regular payment of troops and their quartering and mobilization in case of need. In the sixteenth century, moreover, a militia of both peasants (cernide) and citizens (bombardieri) was created: over 20,000 subjects were organized in the new reserve system, armed and (at least in theory) regularly trained. Likewise, between the fifteenth and the sixteenth centuries the navy's administrative system was properly established, with jurisdiction over timber resources, artillery, gunpowder, crews, payment and supplies. A reserve of oarsmen from the mainland was created; although not very effective, it involved further human resources in the Venetian military machine. So the Republic of Venice was also affected by "a concentration and systematisation of strategically important resources and competencies in order to convert them into something which gives muscle to political power" ${ }^{\text {,3 }}$. This process had to be subsidized with growing amounts of money.

Taxation is the field in which one can best both measure the efficiency of civil administration and gauge the relationship between government and society. We have just seen that one of the crucial features of the fiscal-military state is the notable and steady increase of taxation. Let us see what happened in Venice by considering first some figures and then some institutional aspects.

Tab 5 shows that the Republic's nominal income grew regularly over the early modern centuries. In the fifteenth century it was constant, in the sixteenth century it doubled, and in the early seventeenth it grew again. Between the mid-fourteenth and the mid-fifteenth centuries the Comune Veneciarum was transformed into a territorial state and this dramatic change was mirrored in the amount of revenues - and consequently of financial needs - that grew, in terms of silver, by four times over little more than a century. Over the following period the rate of increase does not look so remarkable, although those years were characterized by a marked rise in prices: the annual

\footnotetext{
${ }^{38}$ Glete (2000), 63.
} 
Table 5

Budgets of the Republic of Venice, 1343-1679

ducats

index $1550=100$

\begin{tabular}{|c|c|c|c|c|c|c|c|c|c|}
\hline & revenue & expenditure & balance & $\begin{array}{l}\text { revenue } \\
\text { index }\end{array}$ & $\begin{array}{l}\text { expenditure } \\
\text { index }\end{array}$ & $\begin{array}{l}\text { revenue } \\
\text { Kg of Ag }\end{array}$ & $\begin{array}{l}\text { expenditure } \\
\mathrm{Kg} \text { of Ag }\end{array}$ & $\begin{array}{l}\text { revenue } \\
\text { hl of wheat }\end{array}$ & $\begin{array}{l}\text { hl of } \\
\text { wheat } \\
\text { index }\end{array}$ \\
\hline 1343 & 250000 & 257000 & -7000 & 16 & 15 & 10256 & 10543 & 270000 & 28 \\
\hline 1344 & 260000 & 285000 & -25000 & 16 & 16 & 10666 & 11692 & 280000 & 29 \\
\hline 1435 & 1100000 & & & & & & & & \\
\hline 1464 & 1120000 & & & 70 & & 46150 & & 1098039 & 113 \\
\hline 1469 & 1120000 & & & 70 & & 46150 & & 1230769 & 127 \\
\hline 1500 & 1150000 & & & 72 & & 44063 & & 958333 & 99 \\
\hline 1550 & 1601000 & 1735000 & -134000 & 100 & 100 & 51130 & 55409 & 971598 & 100 \\
\hline 1555 & 1443000 & 1717000 & -274000 & 90 & 99 & 46084 & 54834 & 704331 & 72 \\
\hline 1558 & 1550000 & 1735000 & -185000 & 97 & 100 & 49501 & 55409 & 715901 & 74 \\
\hline 1565 & 1670000 & & & 104 & & 52079 & & 727130 & 75 \\
\hline 1569 & 1900000 & & & 119 & & 59252 & & 755635 & 78 \\
\hline 1574 & & 1950000 & & & 112 & & 51890 & & \\
\hline 1579 & 1900000 & 2070000 & -170000 & 119 & 119 & 50559 & 55083 & 836513 & 86 \\
\hline 1580 & 2000000 & 2070000 & -70000 & 125 & 119 & 53220 & 55083 & 870842 & 90 \\
\hline 1587 & 2150000 & 1890000 & 260000 & 134 & 109 & 57212 & 50293 & 632462 & 65 \\
\hline 1594 & 2067000 & 2095000 & -28000 & 129 & 121 & 55003 & 55748 & 521182 & 54 \\
\hline 1602 & 2563000 & 2477000 & 86000 & 160 & 143 & 68201 & 65913 & 752740 & 77 \\
\hline 1609 & 2550000 & & & 159 & & 66973 & & 823223 & 85 \\
\hline 1618 & & 2732000 & & & 157 & & 71753 & & \\
\hline 1621 & 3862000 & 3950000 & -88000 & 241 & 228 & 101432 & 103743 & 1178155 & 121 \\
\hline 1623 & 3766000 & 3480000 & 286000 & 235 & 201 & 98910 & 91399 & 1071690 & 110 \\
\hline 1625 & 3560000 & 3240000 & 320000 & 222 & 187 & 93500 & 85095 & 888286 & 91 \\
\hline 1633 & 2950000 & 2650000 & 300000 & 184 & 153 & 77479 & 69600 & 745490 & 77 \\
\hline 1637 & 3020000 & 2870000 & 150000 & 189 & 165 & 60702 & 57687 & 1050127 & 108 \\
\hline 1641 & 2960000 & 2770000 & 190000 & 185 & 160 & 59496 & 55677 & 1047224 & 108 \\
\hline 1665 & 3740000 & 5250000 & -1510000 & 234 & 303 & 72276 & 101456 & 1458959 & 150 \\
\hline 1667 & 4170000 & 3823000 & 347000 & 260 & 220 & 80585 & 73879 & 1649211 & 170 \\
\hline 1670 & 4000000 & 4820000 & -820000 & 250 & 278 & 77300 & 93147 & 1744566 & 180 \\
\hline 1673 & 4000000 & 4460000 & -460000 & 250 & 257 & 77300 & 86190 & 1603091 & 165 \\
\hline 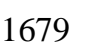 & 4285000 & 3962000 & 323000 & 268 & 228 & 82808 & 76566 & 1571547 & 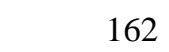 \\
\hline
\end{tabular}

Sources:

Pezzolo (2003). 
growth of 0.2 percent between 1550 and 1609 was quite moderate, considering that wheat prices, in terms of silver, increased annually by $1.37 \%$. Apparently the response to the price conjuncture emerged somewhat late, in the 1630s, when revenues grew considerably. As has been observed, however, it is not easy to correlate the trend of revenues with economic events, for a slight increase in duty rates or a broadening of the products subject to tax is sufficient to distort the result ${ }^{39}$. The 1630 plague hit public finance too, by reducing the tax yield and making recovery slow. It is interesting to note that the 1630 crisis hit harder than that associated with the plague of 1576. In the meantime, in fact, background economic circumstances had changed for the worse; the resources which had been available to recover the revenue level in a short time just after Lepanto were no longer there fifty years later. It is likely that revenue levels' return to their pre-plague amounts coincided with the outbreak of the war for Crete; though there are no data available, it is plausible to argue that government's heavy tax demands increased the revenues to be spent on the navy and the troops fighting on Crete. After the war, the rate of growth remained fairly constant, partly because of the displacement effect created by taxes that had been imposed in wartime and were subsequently maintained.

This rough outline of the trend of central revenues stresses the close correlation with political events concerning the Republic of Venice: military needs - in Venice as elsewhere - prompted revenue increases. It is nonetheless worth noting that from the mid-fifteenth to the mid-sixteenth centuries there were no dramatic changes in ordinary budgets, even though those decades had seen heavy Venetian military commitments both in Italy and overseas. Though prudence is imposed by the lack of detailed financial data from the mid-fifteenth to the mid-sixteenth centuries, the low rate of revenues' growth is still striking: thirty percent between 1469 and the 1550s is not remarkable at all, considering that many new taxes had been imposed and population had also grown. In actual fact, though, other sources suggest a different picture: during the same decades the budgets of the provincial treasury of Bergamo, for example, recorded a revenue increase of about 75 percent ${ }^{40}$. It is thus likely that central budgets had not recorded financial flows which concerned the dominion in years of high military spending. Nonetheless the link between finance and politics stands out clearly throughout the seventeenth century. The early seventeenth century was marked by a steady growth of central revenues; the war for Crete and later that of the Peloponnese (1689-99) prompted a further increase, maybe to a much greater extent than emerges from state budgets. Eighteenth century budgets, with Venice first engaged in the vain defence of the Peloponnese and then in armed neutrality through the European wars of succession, register fairly close correspondence between political events and the rhythm of tax revenues' increase. War therefore set the pace for central revenues'

\footnotetext{
${ }^{39}$ See the interesting remarks of O’Brien and Hunt (1993), 156.

40 Data elaborated from Pezzolo (1998), 64; a similar trend for Brescia: Knapton (1988), 58; Biblioteca del Museo Correr, Venice, Morosini-Grimani, 302.
} 
growth, though at a rate which appears unremarkable compared to other cases studied. Over the same period, in fact, other states' budgets show a much more significant increase, underlining the ever wider difference of scale between the Republic and leading European states.

What did change significantly were certain features of taxation. The forms of taxation grew in number, and - more important - became more effective in comparison with the late middle ages. While a Venetian of Marco Polo's time expected to face the usual excise duties on consumption and a few forced loans (with interest regularly paid), the generation of Vivaldi's youth was subjected to a much wider array of taxes. Besides new levies on goods and transactions, ordinary direct taxes and demands on corporate bodies like guilds and social institutions were taken for granted. Another element to stress is the role attributed to mainland taxpayers, whose share of overall tax revenue had grown in relation to the increasing difficulties of the port and market of Venice, reflected in the yields of its indirect taxes, a turningpoint especially evident between the early and mid seventeenth century.

It must be said that budget figures are unsuitable for univocal interpretation. Behind the growth of revenues historians have too often wanted to read the success of central authority, the victory of central regulative rationality over local particularism, the emergence of a 'public' financial system favoring the birth of the 'modern' state. A totally different view of state development and revenue dynamics has recently been proposed: regimes with strong representative institutions tend to show both more effective public finance and a higher capacity for actually collecting taxes than absolutist states ${ }^{41}$. This means that legitimacy and negotiation rather than coercion lay at the base of good performance by a fiscalfinancial system. A system mostly relying on bargaining between wellrepresented social bodies would significantly lower what the language of neo-institutional economics defines as transaction costs: negotiation, information, collection, enforcement etc. In adopting this perspective, it is worth while looking briefly at the constitutional structure of the Venetian state.

Political power was the prerogative of the Venetian nobility, which had turned into a closed group between the late thirteenth and the early fourteenth centuries. From then to the end of the republic in 1797 the Venetian patriciate was a veritable caste. However, shared commercial interests and the working of trade constituted part of the common ground between the patriciate and the rest of the Venetian population. Therefore a war whose purpose was to establish or maintain control over a strategic area, or against Genoa, was felt to be an enterprise involving the whole city. It is very likely that in wars from the thirteenth to the fifteenth centuries, government tax demands met with a reasonably positive response among Venetians, who largely agreed with the war's aims in the expectation of generally enhanced prosperity. In the fifteenth century, the formation of a territorial state in northeast Italy allowed Venetian government to

${ }^{41}$ Hoffman and Norberg (1994), 299-310. 
considerably increase the number of taxpayers, but it also had to cope with a new problem posed by the recalcitrance of provincial élites, particularly those of wealthy and populous cities like Padua, Vicenza, Verona, and Brescia. Annexation of the dominion had taken place with the mixed use of armed might and the granting of privileges and prerogatives to conciliate these new subjects, as was the usual practice in political relations between center and periphery. The Venetian territorial state was thus built on marked differences between separate categories of taxpayers: Venetians, inhabitants of the subject cities, peasants. It must however be stressed that as a rule no one was exempt from taxes; the doge himself was subject to tax. Nonetheless the state's fiscal geography was composite, and it is reasonable to assert that the extent of fiscal control exerted by government was directly proportional to the distance from the capital, and might also be mitigated by the strategic importance recognized for some territories, for example mountain communities near foreign borders. But maybe the most important feature of Venetian state structure was the sharp separation of political roles between Venice and its mainland: the provincial élites could not aspire to enter the ruling élite of Venice itself, and therefore gain acces to important state office. Whereas in other states the emergence of administrative and military systems brought about significant social and political mobility, in the Venetian state every upward move was blocked by the constitutional structure, which was entirely dominated by the patrician caste of the capital city. This also meant that the Venetian republic lacked a crucial means for state development - a large bureaucracy - that could not only make the enforcement of government's will more effective but, more importantly, attract both provincial élites and emerging social groups.

Institutional representation of the mainland élites was an element missing from the core of the political system. So fiscal relations were characterized by the high incidence of wearisome negotiations and second thoughts. No doubt such a situation brought about high transaction costs, yet it would be wrong simply to infer that the Venetian fiscal system was ineffective. The Venetian patricians left considerable space to local élites in the management, assessment and distribution of tax burdens. Fiscal yield can therefore be regarded as the outcome of a compromise between central government and provincial élites. In the Venetian republic tax revolts occurred very seldom, and only lasted for a few days. The army was considered much more as a military device than as a means for controlling or coercing subjects.

The Venetian state of the late middle ages was a lightweight state. Both the military machine and the administrative system were certainly neither large nor effective. Although there was a high incidence of warfare during the thirteenth and fourteenth centuries, it did not bring about the major development of the Venetian state structure, which maintained the characteristics of a city-state. Ironically, some results attributed to the fiscalmilitary state were attained by a state structure that was small but nonetheless proved able to mobilize huge resources quickly and to 
transform them into potent means of war. Even though it was an almost daily event in Venetian history, naval warfare does not seem to have played a crucial role in state development. Those who fought on Venetian galleys in major battles in the medieval Mediterranean were mostly merchants, artisans and laborers, who after the campaign returned to ordinary occupations, while many of the ships used were quickly returned to their normal commercial usage. Very little remained of the military machine that had been mobilized; institutions specialized in military administration were few and subject to a high turn-over among the patricians in charge of them.

Venice's decline started as both Ottoman power and strong European competitors emerged. Until Lepanto, however, Venice could still be considered a great naval power; scant technological innovation in the naval sector and government incapacity to improve military organization then led gradually to a real crisis of the navy. The tax system, on the other hand, continued to prove quite effective and, along with the public debt, provided enormous financial resources that were not fully exploited.

War was however certainly a catalyst for some developments. The wars against the Ottomans from the fifteenth to the early eighteenth centuries offered a key argument in legitimizing further taxing. Venetian government claimed legitimacy in taxing because it fought its wars in the defence of Christendom against the Muslims, and was thus able to get money out of its clerical subjects, who were theoretically considered primarily as taxpayers of the Church. Moreover, war mobilized material and spiritual resources as well. State iconography stressed Venice's role as the bulwark of Christendom; and the long struggle against the Turks involved mainland subjects too, who gave considerable support to Venice's war effort. Nevertheless, the Republic's traditional instrument of war - the navy - remained something unrelated to the experience of most Venetian subjects. Likewise, the land army was seen by government as an institution substantially unconnected with the traditions of the capital. Military organization thus mirrored the crucial weakness of the Venetian state: the profound division between the lagoon city and patrician government on the one hand and, on the other, the mainland and its local élites. The two worlds were primarily linked via clientage bonds, which allowed the Venetian patricians to maintain sufficient control of the dominion but prevented them from building a homogeneous state. 


\section{References}

Agnoletti, M. (1996). “Aspetti tecnici ed economici del commercio del legname in Cadore (XIV-XVI secolo.” In S. Cavaciocchi, (ed.), L'uomo e la foresta, Firenze: Le Monnier, 1025-40.

Aymard, M. (1994). “La leva marittima”. In A. Tenenti and U. Tucci (eds.), Storia di Venezia, Il mare, Roma: Istituto della Enciclopedia Italiana.

Aymard, M. (1974). "Chiourmes et galères dans la seconde moitié du XVIe siècle.” In G. Benzoni (ed.), Il Mediterraneo nella seconda metà del '500 alla luce di Lepanto, Firenze: Olschki.

Bamford, P. W. (1973). Fighting ships and prisons. The Mediterranean galleys of France in the age of Louis XIV, Minneapolis: University of Minnesota Press.

Bin, A. (1992). La repubblica di Venezia e la questione adriatica 16001620, Roma: Il Veltro.

Brewer, J. (1989). The sinews of power. War, money and the English state, 1688-1783, New York, A. Knopf.

Calegari, M. (1973). “Legname e costruzioni navali nel Cinquecento.” In Guerra e commercio nell'evoluzione della marina genovese, 2, Genova: Società Ligure di Storia Patria.

Celetti, D. (2001-02). "Fustagni e 'canevazze' per le vele della marina veneta tra '500 e '700", Atti dell'Istituto veneto di scienze, lettere ed arti, $160,795-848$.

Celetti, D. (2002). 'L’industria navale veneta e olandese in età moderna. Peculiarità e risultati di due modelli di sviluppo settoriale', Storia economica, 5, 257-90.

Celetti, D. (2003). “Il prezzo della canapa in età moderna. L'interazione del mercato, della moneta e dello stato nella determinazione del valore di una fibra 'strategica”, Storia economica, 6, 5-47.

Davis, R.C. (1991). Shipbuilders of the Venetian Arsenal. Workers and workplace in the preindustrial city, Baltimore and London: Johns Hopkins University Press.

Doumerc, B. (1997). “La difesa dell’impero.” In G. Arnaldi, G. Cracco, and A. Tenenti (eds.), Storia di Venezia, 3, Roma: Enciclopedia Italiana, 237-50

Epstein, S.A. (1996). Genoa and the Genoese, 958-1528, Chapel Hill and London: North Carolina University Press. 
Glete, J. (2000), Warfare at sea, 1500-1650. Maritime conflicts and the transformation of Europe, London: Routledge.

Greif, A. (1998). "Self-enforcing political systems and economic growth: late medieval Genoa.” In R.H. Bates, A. Greif, M. Levi, J.-L. Rosenthal, and B.R. Weingast, Analytic narratives, Princeton: Princeton University Press.

Guilmartin, J. F. (2003). Gunpowder and galleys. Changing technology and Mediterranean warfare at sea in the $16^{\text {th }}$ century, London: Conway Maritime Press (first ed. Cambridge 1974).

Hale, J.R. (1983). Renaissance war studies, London: Hambledon Press.

Hocquet, J-C. (1978-79). Le sel et la fortunede Venise, Lille : Publications de l’Université de Lille, 2 vols.

Hoffman, P.T., and Norberg (eds.) (1994). Fiscal crises, liberty, and representative government, 1450-1789, Stanford, Stanford University Press, 1994

Jacoby, D. (1981). "Les gens de mer dans la marine de guerre vénitienne de la mer Egée aux XIVe et XVe siècles.” In R. Ragosta (ed.), Le genti del mare Mediterraneo, Napoli : Giannini, 169-201.

Knapton, M. (1988). "Cenni sulle strutture fiscali nel Bresciano nella prima metà del Settecento”. In M. Pegrari (ed.), La società bresciana e l'opera di Giacomo Ceruti, Brescia:

Koerner, M. (19945). “Expenditure.” In R. Bonney (ed.), Economic systems and state finance, Oxford: Clarendon Press.

Lane, F. (1932). "The rope factory and hemp trade of Venice in the fifteenth and sixteenth centuries." Journal of economic and business history, 4, 83047.

Lane, F. (1965). Navires et constructeurs à Venise pendant la Renaissance, Paris : S.E.V.P.E.N.

Lane, F. (1973). “Naval actions and fleet organisation, 1499-1502.” In J.R. Hale (ed.), Renaissance Venice, London: Faber and Faber.

Lane, F.(1973). Venice. A maritime republic, Baltimore and London: Johns Hopkins University Press.

Lane, F. (1983). Le navi di Venezia, Torino: Einaudi. 
Mackenney, R. (1987), Tradesmen and traders. The world of the guilds in Venice and Europe, c.1250-c.1650, London and Sidney: Croom Helm.

Mallett, M. and Hale, J.R. (1984). The military organisation of a renaissance state: Venice c. 1400 to 1617, Cambridge: Cambridge University Press.

O'Brien P.K. and Hunt P.A. (1993). "The rise of the fiscal state in England, 1485-1815.” Historical research, 66, 129-76

Pastori Bassetto, I. (1993). “La canapa nella Repubblica veneta.” Archivio veneto, 141.

Pezzolo, L. (1990). L'oro dello Stato. Società, finanza e fisco nella Repubblica veneta del secondo '500, Venezia: Il Cardo.

Pezzolo, L. (2003). La finanza pubblica veneziana in età moderna, Working Paper, Venezia: Dipartimento di Scienze Economiche

Pezzolo, L. (forthcoming). Il ferro e l'oro. Istituzioni militari e finanze in Italia, 1400-1700.

Rolnick, A., Velde, F., and Weber, W.E. (1996). "The debasement puzzle. An essay on medieval monetary history." Journal of economic history, 56, 789-809.

Romano, R. (1954). “Aspetti economici degli armamenti navali veneziani nel secolo XVI.” Rivista storica italiana, 66, 40-67.

Tenenti, A. (1961). Venezia e i corsari 1580-1615, Bari: Laterza.

Tenenti, A. (1962). Cristoforo Da Canal. La marine vénitienne avant Lépante, Paris : S.E.V.P.E.N.

Viaro, A. (1981). "La pena della galera. La condizione dei condannati a bordo delle galere veneziane.” In G. Cozzi (ed.), Stato società e giustizia nella Repubblica di Venezia (sec. XV-XVIII), Roma: Jouvence.

Wheeler, J.S. (1999). The making of a world power. War and the military revolution in seventeenth-century England, Phoenix Mill: Sutton.

Zug Tucci, H. (1997). "Le milizie terrestri.” In G. Arnaldi, G. Cracco, and A. Tenenti (eds.), Storia di Venezia, 3, Roma: Enciclopedia Italiana, 251-96. 